\title{
The Formation of a Management System of Electronic State and Municipal Services of the Region
}

\author{
Irina Ershova \\ Department of Finance and Credit \\ Southwest State University \\ Kursk, Russia \\ E-mail: ershovairgen@yandex.ru
}

Liliy Guselnikova

Department of Finance and Credit

Southwest State University

Kursk, Russia

E-mail: pereverzeva.lilia@yandex.ru

\author{
Elizaveta Yakimova \\ Department of Finance and Credit \\ Southwest State University \\ Kursk, Russia \\ E-mail: ersho.elizaveta@yandex.ru
}

\author{
Tatiana Kolmykova \\ Department of Finance and Credit \\ Southwest State University \\ Kursk, Russia \\ E-mail: auershov@mail.ru
}

\begin{abstract}
The relevance of the paper is confirmed by the fact that regional information systems can facilitate the placement of state and municipal orders by automating routine processes related to the planning, formation, implementation and control of procurement of public institutions in the region. The purpose of this study is to study the management system of electronic state and municipal services in the region. To achieve this goal, the following tasks were solved: this article presents an analysis of the regulatory framework for the provision of state and municipal services in the region; monitoring of the quality of state and municipal services in the region; proposed ways to improve the quality of state and municipal services. This paper uses theoretical and empirical research methods, such as literature review, system analysis and review of world statistics. Sources of information are economic and other specialized literature, articles from periodicals, research results, experience of leading foreign companies. This article uses economic-mathematical and statistical methods of analysis. The result of this paper is the conclusion about the development of modern management system of electronic state and municipal services in the region. The priority directions of development of informatization in state and municipal management, at present, are the integration of the created disparate information systems of management bodies in complex information systems, the development of information infrastructure, the formation and use of information resources - cadastres, registers, distributed databases, the introduction of an automated system of electronic document management, the creation of e-Commerce centers and public procurement, the creation of Internet portals of public authorities and local governments.
\end{abstract}

Keywords-management system; municipal services of the region; electronic state and municipal services

\section{INTRODUCTION}

Modern conditions require a high level of Informatization of the environment of state and municipal administration.
Each state and municipal entity must have a minimum set of information attributes for effective management. The organization of work of public administration and local selfgovernment bodies on the basis of information and communication technologies is a priority in the e-state program

In 2005-2010, the concept of administrative reform was adopted, including the transformation of approaches to the provision of state and municipal services, and the plan of measures for its implementation for 2006-2010, in order to improve the quality and availability of state and municipal services, to overcome administrative barriers to business, to improve the efficiency of state bodies and interdepartmental interaction, to improve the openness and transparency of the activities of state bodies. Multifunctional centers operating on the basis of the Federal law of the Russian Federation of July 27, 2010 № 210-FZ "on the organization of state and municipal services" were established. The analyzed legal act laid the basis for detailed regulation of the relationship arising in connection with the provision of state and municipal services in the region [1].

These measures have greatly facilitated and improved the provision of services to the population and business in the region.

As of January 1, 2017, 2,820 centers and 1,098 offices providing state and municipal services were established on the territory of the Russian Federation. The value of the onestop-shop coverage rate was more than $94 \%$.

Important legal acts regulating the organization of work, the basis of management, as well as the responsibility of multifunctional centers (hereinafter - MFC), providing state and municipal services, are two Federal laws: Federal Law of 03.11.2006 № 174-FZ "on Autonomous institutions" and Federal law of 12.01.1996 № 7-FZ "on non-profit organizations". One of the basic principles of the provision 
municipal services. In her opinion, "the legal platform is a set of ideologies, concepts, doctrines, strategies, plans, programs and legal norms for their implementation on behalf of the state power".

Thus, the implementation of a variety of different legal acts in the process of activities of authorized entities is the legal support of this activity. The starting point for the formation of regulatory support for the provision of state and municipal services is the current legislation of the Russian Federation. Despite the fact that the legislation in the issues under consideration has been repeatedly criticized, while there are difficulties in its development, at the moment it is possible to talk about the existing legal regulation of the provision of state and municipal services in the country [3].

\section{MONITORING THE QUALITY OF PUBLIC AND MUNICIPAL SERVICES IN THE REGION}

In 2017, the Executive authorities and local authorities of the Kursk region monitored the quality of public and municipal services.

Monitoring was carried out to assess the effectiveness of the Executive authorities of the Kursk region and local governments to achieve the targets of improving the system of public administration. During the monitoring it was possible to identify the most problematic areas of public and municipal services, as well as to track the dynamics of the main indicators of the most mass services. During the monitoring were studied indicators related to the assessment of the quality of services and evaluation of the activities of the Executive authorities of the Kursk region and local authorities:

- information support of services;

- the financial and time costs for applicants to obtain services;

- the degree of compliance with authority standards for the provision of services;

- determining the level of satisfaction of applicants with the quality and availability of services;

- determining the degree of optimization of the order and quality of services;

- assessment of the activities of the authority for amending existing regulations;

- assessment of quality design of administrative regulations on the provision of services;

- determination of the degree of readiness of authorities to provide services in electronic form using interdepartmental information exchange.

The monitoring was carried out in relation to the most mass and socially significant state and municipal services provided by the local authorities of the Kursk region. 19 Executive authorities of Kursk region, 28 municipal districts and 5 urban districts took part in the monitoring. In total,
Bachilo I. L. writes about the need to develop a comprehensive legal platform for the development of a variety of opportunities for the provision of state and 
date, in a timely manner to place them on the website of the administration of the Kursk region, the websites of municipalities.

The Executive bodies of Kursk region of respondents 7365 people receiving public services, that more compared to 2016 (2980 people, or 40\%). Also in the field of social services the number of respondents increased from 190 people in 2016 to 1154 in 2017, the survey was conducted among residents of 28 municipal districts and the city of Kursk. Local self - government bodies of the region interviewed 4116 recipients of municipal (state on transferred powers) services addressed to local selfgovernment bodies of the region. Only the survey conducted for 240 service, including 50 of 190 state and municipal services.

The highest degree of awareness about the receipt of public services $(100 \%)$ was noted among the applicants interviewed by the health Committee of the Kursk region, the state Inspectorate of the Kursk region for supervision of the technical condition of self-propelled machines and other types of equipment with the relevant state inspections of cities and districts, the Committee of construction and architecture of the Kursk region, the Department of environmental safety and environmental management of the Kursk region, the Committee of industry, transport and communications of the Kursk region [5].

This figure is lower in the Committee of education and science of Kursk region $-71.4 \%$, in the Department for the protection of cultural heritage of Kursk region $-57.1 \%$, and the lowest - in the forestry Committee of Kursk region $45 \%$.

In Local governments of the region applicants are well informed about the methods and procedure for obtaining municipal services. They receive information from information stands posted in the places of municipal services, from materials published in local Newspapers, from the official websites of district Administrations and village councils, the administration of the Kursk region [6].

According to the results of the monitoring, the following conclusions can be drawn:

- information support for the provision of state and municipal services generally satisfies the applicants and meets the requirements of the current legislation.

- administrative regulations for the provision of services contain the necessary information on the procedure and conditions for the provision of services.

- there is A high degree of readiness of Executive authorities and local authorities to provide services in electronic form.

- there is a positive trend in the level of satisfaction of applicants with the quality and availability of services received in 2015, 2016 in 2017.

In order to improve the quality of public and municipal services offered:

- make timely changes to the existing regulatory framework. Administrative regulations to keep up to
- to inform applicants more Widely about the possibilities of obtaining services through the Unified portal of state and municipal services (functions), the Portal of state and municipal services of the Kursk region. For this purpose it is necessary to carry out the following actions:

Carry out activities to improve computer literacy to obtain services using the Internet;

Inform citizens about the possibilities of obtaining services in electronic form through the Unified and regional Portals of public services;

Explain the Rules of use of the Unified and regional Portals of public services and Private office.

- to inform applicants more Widely about the possibility of receiving services through multifunctional centers and its branches in the "onestop-shop" mode.

- publish news and information materials on the provision of services in electronic form, post information materials in places of mass stay of people and advertising structures.

\section{DIRECTIONS OF IMPROVING THE QUALITY OF STATE AND MUNICIPAL SERVICES}

The quality of the provision of state and municipal services (by which we mean a specific result obtained by an individual or a legal entity as a result of interaction with a certain authority or local government and representing the implementation of the relevant authority or local government of its functions) causes reasonable complaints among the population and business representatives [7]:

- State and municipal institutions work according to an inconvenient schedule, coinciding with the usual time of work of other organizations. For this reason, people have to be asked to visit a public institution (the employer may not always and considers it necessary to release the employee). Time of absence of the worker on a workplace is not paid, and the employer has the right to demand from the employee or to fulfill this time, or to deduct the corresponding sum from his salary.

- in some cases, in order to obtain a certain public service, it is necessary to visit several public institutions, the schedule of reception of visitors in which is not agreed, and they can be in completely different places. This increases the cost of a citizen to visit institutions and, as a result, extends the duration of his absence from the workplace.

- in most public institutions, the number of reception days is limited, in addition, even on these days, the reception of citizens is usually not carried out all day. 
This means that the most effective solution to these Because of this, there are long queues, often people get to the official not the first time, which causes quite natural discontent.

- unfortunately, despite all the declarations on the construction of the service state, civil servants do not treat visitors as full-fledged consumers of public services, but as an annoying obstacle that distracts them from their main activities. This is reflected in the unfriendly attitude to visitors and the disregard for their interests.

It is obvious that from all the above it is necessary to take the following measures:

- the organization of a more convenient schedule of reception of citizens (in particular, after working day and on weekends), and the introduction of more reception days.

- the organization of a" single window", so that a citizen interested in obtaining any public service that requires a visit to several institutions, could bring his application and the necessary documents to one of these organizations (or a specially created for such purposes public authority), and the passage of documents to the authorities would provide themselves employees of state bodies.

- creation of motivation of civil servants to polite and friendly interaction with the population and to effective satisfaction of their requests.

Unfortunately, the implementation of these activities within the framework of the current model of public services delivery faces a number of problems.

The introduction of a more convenient schedule of reception will require the allocation of additional staff to interact with the population, in other words, it will be necessary to recruit civil servants, and, as a result, an increase in budget expenditures for the maintenance of the state apparatus. It will be difficult to compensate for these costs, since the tariffs for the provision of public services are fixed [8]

The organization of the "single window" will also require significant costs - this time to change the algorithm for the provision of public services and to allocate special employees who will interact between different institutions involved in the process of providing one public service. The alternative would be a hard binding of the whole complex of actions within a single submission to a single government Department, but this will require a redistribution of competencies between bodies of state power, and, moreover, is not always feasible.

Finally, changing the attitude of civil servants to the population requires significant institutional changes, in fact-a change in the social identification of both citizens and representatives of the authorities. These changes are unlikely to be implemented in a short period of time, especially given that a management Directive is not enough to implement them - a change in mentality must come from within [9]. problems could be the introduction of an intermediary between the state apparatus and the population, which would coordinate the interaction of state bodies and citizens for their mutual convenience.

Such intermediaries are currently multifunctional centres for the provision of public services. They introduced the principle of "single window", they work on a convenient schedule for the population, and employees are set to work effectively for citizens. In fact, from an organizational point of view, these multifunctional centers act as virtual organization cores created for each specific request.

However, this approach is also not free of drawbacks. It requires significant costs (at least to pay for the premises and labor of employees of the multifunctional center), as well as the personal presence of the citizen. In addition, in our opinion, it represents a certain social danger: the use of outsourcing in the provision of public services (and such intermediaries act as outsourcers) can create the public opinion that public authorities are not able to perform their functions independently.

Much more effective would be the use of technologies of electronic interaction between the government and the population. If the situation is somewhat simplified, the provision of state or municipal services consists in the processing and registration of certain information. Thus, the transfer of public services in electronic format is a natural way to improve the quality of their provision [10].

So far, the potential of such technologies remains largely untapped. Both due to legal restrictions and due to the Russian mentality, only a part of operations is transferred to electronic format, while the full provision of public services requires the personal presence of a citizen. However, the active introduction of such technologies would allow to achieve a number of important economic and social effects:

- possibility of reducing the number of civil servants by eliminating personal interaction with the public and moving to automated information processing. This will reduce the cost of maintaining the state apparatus and increase its manageability and quality of work;

- population will not have to spend time to be present in public institutions, as applications can be sent at a convenient time from any computer;

- ability to track the passage of the application online;

- increase the transparency of the work of the authorities. In addition, the electronic format is convenient to store the entire history of interaction between the citizen and the authority, which can simplify the settlement of claims and litigation;

- state will be perceived as more open to the population, which is extremely important in modern conditions. To solve this problem, along with the official websites, it could be recommended to state agencies to ensure their presence in social networks. 
The development of the information society of the region is characterized by priorities in the formation of the technical and technological basis of the information society, the creation of modern ICT infrastructure, information security. Despite the fact that much attention is paid to the development of regional Informatization in the region, the lack of funding in this area, complicates this process.

Works in the field of automation and application of new information technologies in the region are carried out in the following main areas:

- organization of development, implementation and maintenance of software and hardware systems of local telecommunications networks related to the maintenance of information databases;

- introduction of advanced forms and methods of processing industry information, participation in the formation of a unified information system of the region;

- implementation of methodological,information, software and technical support of Executive authorities on Informatization.

Regional Informatization is carried out in several directions, the basic of which are: education, health, transport, construction, life safety, social protection of the population and culture. On the basis of the analysis it can be argued that the Kursk region has the potential to improve the performance of regional Informatization, and, consequently, the possibility of increasing its position in the final ranking of the level of development of the information society in the subjects of the Russian Federation.

\section{REFERENCES}

[1] E. Kharchenko, I.Garbuz Mechanisms Of National Economy And Its Regions Adaptation To The Conditions Of Integration To The World Economy (2016). // Економічний часопис-XXI. № 3-4-1 (157). C. 28-31.

[2] I. Ershova, I. Androsova., S.Morkovina Methodical approaches to assessment of intellectual rent as a factor of innovative economy development (2016) 3-rd International multidisciplinary scientific conference of social sciences and arts SGEM 2016. 24-30 August 2016. Conference proceedings: Political sciences, law, finance, economics and tourism. Volume V: Economics and tourism. Albena, Bulgaria, 2016. pp. 425-430.

[3] A. Anisimov, A. Zhaglovskaya, A. Kudra, A.Obukhova, Y. Aleksakhina Strategic Approach To Forming A Human Resource Management System In The Organization (2017). International Journal of Economic Perspectives. T. 11. № 2. C. 442-448.

[4] E. Belyaeva, T. Svetovtseva Main Trends Of Factoring Market Development At Present Economic Conditions (2016). Економічний часопис-XXI. № 3-4-1 (157). С. 65-67.

[5] I. Ershova, O. Sogacheva, A. Devyatilova Public-Private Partnershipsin The Implementation Of Cluster Initiatives (2016) B сборнике: Innovation Management and Education Excellence Vision 2020: From Regional Development Sustainability to Global Economic Growth, IBIMA 2016 Proceedings of the 27th International Business Information Management Association Conference. C. 1119-1125.

[6] Y. Vertakova, Y. Polozhentseva, M Klevtsova. Management Of Innovative Processes In Industry: Method Of "Road Maps" (2016) B сборнике: Vision 2020: Innovation Management, Development 
Sustainability, and Competitive Economic Growth Proceedings of the 28th International Business Information Management Association Conference. Editor Khalid S. Soliman. C. 2168-2178.

[7] I. Ershova, A. Ershov Development of a strategy of Import Substitution (2016) Procedia Economics and Finance, Volume 39, 2016, Pages 620-624.

[8] T. Kolmykova, S. Emelyanov, E. Merzlyakova Research Of Innovative Potential Of The Region (2017). Journal of Applied Engineering Science. T. 15. № 3. C. 276-279.

[9] G. Ayed, S. Ghernaouti-Hélie, Service-oriented digital identityrelated privacy interoperability: Implementation framework of Privacy-as-a-Set-of-Services (PaaSS) (2012) Lecture Notes in Business Information Processing.

[10] T. Kolmykova, E. Merzlyakova, V. Bredikhin, T. Tolstykh, O. Ovchinnikova Problems Of Formation Of Perspective Growth Points Of High-Tech Productions (2018). Advances in Intelligent Systems and Computing. T. 622. C. 469-475

[11] L. Shirokova, P. Pochechun Modelling Of Regional Corporate Environment Development (2016). Економічний часопис-XXI. № 3-4-1 (157). C. 91-93. 